\title{
The Impact of Academic Supervision and Classroom Action Research Training on Professional Competence of Elementary School Teacher
}

\author{
Aribowo \\ \{bowo.sundoro13@gmail.com\} \\ Faculty of Teaching and Education, Universitas Muria Kudus \\ Gondang Manis PO. BOX 53 Bae, Kudus, Central Java, Indonesia \\ Phone (+62291) 438229, Fax (+62291)437198
}

\begin{abstract}
There are some steps to improve teacher professional competencies including academy supervision and classroom action research training. The purpose of this study is 1) To know the effect of academic supervision on the professional competencies of elementary school teachers, 2) To know the effect of classroom action research training on the professional competencies of elementary school teachers, 3) To know the effect of academic supervision and classroom action research training on the professional competencies of elementary school teachers. The subject of this study were all elementary school teachers in all Subdistricts of Undaan, Kudus Regency. This study uses a quantitative contribution method with regression analysis techniques. Respondents were selected using a purposive sampling technique. Data collection research using a questionnaire. The validity of data uses construct validity by way of experiential juggment. Data analysis was perfomed using regression analysis techniques in the form of simple and multiple regression. The results of the study showed that academic supervision had an effect on teacher professional competence. whereas classroom action research training has an effect on teacher professional competence. Academic supervision and classroom action research training together have an effect on teacher professional competence.
\end{abstract}

Keywords : Academic Supervision, Classroom Action Research Training, Professional Competence

\section{Introduction}

In era industrial revolutin 4.0 now all done with modern technology and professional staff. The shange also occurred in the field of education. Teachers in the industrial revolution 4.0 are required to work professionally. Especially with the existence of professional allowance, teachers must be more professional at work. The teacher is one of the most important school components in the framework of implementing the curriculum, this is due to the teacher having a great responsibility in the learning process at school. Teachers are required to be able to translate competency standards and basic competencies so that it becomes interesting learning material. To be able to master this, of course only teachers who have professional 
competence are able to carry it out. This is implied in Govemment Regulation Number 19 of 2005 concerning National Education Standards, in the elucidation section of Article 28 Paragraph (3) point (c) it is explained that what is meant by professional competence is the ability to master extensive and in-dedth learning material that enable it to guide students to meet the competency standards stipulated in the National Education Standards. Teacher Professional Competence can also be seen from UKG, because teachers will be given tests on pedagogical and professional abilities. Based on the results of the 2015 teachers in Undaan District received an average score of 62.47 with a percentage of teachers who did not pass the KKM $28.10 \%$. Based on the above data, professional competence of elementary school teachers is still a focus of urgent problems to immediately find a solution so that the professional competence of elementary school teacher can increase.

According to [2]Bafadal (2009) states that supervision activities carried out continuously can improve teacher professional competence. The teacher needs to get help from the mentor in order to maximize his finction professionally. One of the supervision activities is a academic supervision conducted by the school principal. According to [11]Asih Pratiwi (2013) states that the academic supervision of the principal has a positive and significant influence on the professional competence of teachers. This show that academicthat supervision by the school principal has a positive influence on the professional competence of teachers. Academic supervision contributes to improving teacher professional competence.

According to [18]Wokneh, A \& Tassew, W(2013) "teacher training, capacity building and work experienve have positive affects on quality education" which explains that teacher training, capacity building and work experience have a positive effect on the quality of education. With teacher training can improve the quality of education one of which is the professuonal competence of teacher.

According to [4]Hardono, Haryono, \& Amin Yusuf (2017) stated that academic supervision is an activity of providing assistance to teacher in oerder to assust teacher in the lerarning process which consists of planning, implementing and evaluating learning in order to achieve planned objectives. So that academic supervisior provides service and assistance to teacher to improve quality in the learning process. Being according to [1] Arikunto Suharsimi \& Lia Yuliana (2013: 280) The main objective of academi supervision is to improve the professional abilities of teacher and improve the quality of learning through good learning.[12] Sagala (2010: 187) divides academic supervision techniques into individual acdemic supervision techniques and grub academic supervision technique. Implementation of professional supervision and good teacher competency according to [5] Kompri (2015: 264265) can be done in following manner: (1) motivating teacher to keep working well is not an easy job, (2) giving encouragement to teacher to not work monotonously, (3) the principal needs to uphold the discipline of teachers by giving an exampel with supervision and sanctions, (4) the principal urges teacher to want to try to improve their profession. [5] Azhar ( Komri, 2015: 268-269) said that the way to utilize the results of academic supervision as follow: (1) provide suggestion for improvement for the problems found, (2) report fidings/ deviations to be implemented as appropriate, (3) conduct case conference, (4) the results of supervision are reported in writing to the supervisior and to yhe education guidance officer.

From the description above it can be conclude that academic sepervision is professional assistence te teachers through a cycle of systematic planning, careful observation, and objective and immediante feedback. Academic supervision is an activity of providing assistance to teachers in order to assist in the learning process which consists of planning, implementing, and evaluating learning in order to achieve the planned objectives. In this study, academic supervision is only in the process of implementing academic supervision and 
in the follow-up process of academic supervision. With the academic supervision will increase the professional competence of teacher in teaching to be more professional.

According to [7]Dessler (Mulyanti 2018) Training is the process of teaching the skill needed by new employees to do their jobs. According to [7]Mangkunegara (Mulyanti 2018) The objectives of training and development inclede : increasing mental and ideological comprehension, increasing work productivity, improving work quality, improving the determination of human resource planning, increasing moral attitude and work morale, increasing stimulation so that employees are able to excel to the maximum, improve work health and safety, avoid obsolescence, improve personal development. According to [3]Bangun (2012: 208-210) there are four levels of assessment of training namely: a) Reaction, b) learning, c) Behavior, d) Training results. Understanding classroom action research training according to [17]Wardhani (2014: 1.4) states that classroom action research is research conducted by teachers in their own classes through self-reflection with the aim to improve their performance as a teacher, so that student learning outcomes improve. According to [16]Tampubolon (2014: 25) said the specific purpose of classroom action research is to improve the quality of teaching practices in a continuous class.

Based on the expert opinion above, it can be concluded that training is a learning experience in making changes to improve technical knowledge/skill, conceptual abilities and ability to do work. There are four levels of assessment of training, including: Reaction, learning, Behavior, Training results. Classroom action research can be interpreted as a reflective form of study by action actors, which is carried out to improve rational stability and their actions in carrying out task, deepen understanding of the action carried out, and improve conditions where practices are learning is done. The benefits of classroom action research are to produce classroom action research to improve the quality of learning, foster the habit of writing research for teachers, collaboration between teachers in solving learning problems, increasing the ability of teachers to describe learning programs, increasing student learning outcomes, the realization of interesting and fun learning.

According to [9]Mulyasa (2013: 42) professional competence is the ability of educators in mastering broad and in-depth learning material that enables guiding students to obtain the specified competencies. The foundation in professional knowledge can be used as a guide for teachers to develop their competencies, especially professional competencies. Indicators that can be used to determine professional competence of teachers are in Permendiknas No. 16 of 2007, which explains that teacher professional competence has five aspects, namely : (a) mastering the material, structure, concepts, and scientific mindset that supports the subjects being taught, (b) mastering the competency standards and basic competencies of subjects of development who are able, (c) develop learning material that is taught creatively, (d) develop professionalism in a sustainable manner by taking reflective actions, (e) utilizing technology and communication to communicate and develop themselves. While more specifically according to [8]Mulyasa (2007: 136-138) professional competence of teachers can be described as follows : understanding national education standards, developing educational unit level curricula, mastering standard materials, managing learning programs, managing classes, using media and learning resources, mastering educational foundations, understanding and implementing student development, understanding and organizing school administration, understanding research in learning, displaying exemplary and leadership in learning, developing theories and basic concepts of education, understanding and implementing individual learning concept.

From the description above it can be concluded that professional competence is the ability of educators in matering broad and in-depth learning material that allows guiding 
students to obtain the specified competencies. The professional competencies discussed in this study include : (1) mastering the material, structure, concepts, and scientific mindset that supports the subjects being taught, (2) mastering the competency standards and basic competencies of subjects of development that are supported, (3) develop learning material that is taught creatively, (4) develop professionalism in a sustainable manner by taking reflective actions, (5) utilizing technology and communication to communicate and develop themselves. Strategies in developing professional competence of teachers are as follows : improvement in professional abilities of teachers is carried out through academic supervision activities by school principals, enhancing teacher professional competency can also be done through teacher centers in the form of training.

Based on the explanation above, it can seen that academic supervision and classroom action research training has an influence on teacher professional competence which includes five aspects including : mastering material, structure, concepts, and scientific mindset that supports the subjects, mastering the competency standards and basic competencies of subjects, developing material learning creatively, developing professionalism in a sustainable manner by taking reflective actions, utilizing technology and communication to communicate and develop themselves.

The formulation of the problem can be compiled based on the description above as follows : how much the effect of academic supervision on the professional competencies of elementary school teachers in the Undaan District, Kudus Regency?, how much the effect of classroom action research training on the professional competencies of elementary school teachers in the Undaan District, Kudus Regency?, how much the effect of academic supervision and classroom action research training on the professional competencies of elementary school teachers in the Undaan District, Kudus Regency?

The purpose of this study is 1) To know the effect of academic supervision on the professional competencies of elementary school teachers, 2) To know the effect of classroom action research training on the professional competencies of elementary school teachers, 3) To know the effect of academic supervision and classroom action research training on the professional competencies of elementary school teachers.

\section{Method}

The researcher designs the research as a survey research to determine whether or not there is an influence between two or more variable and how much influence. The approach used is a contribution quantitative approach that is conduction a study of the facts and the results of the study will provide an overview of the influence between academic supervision, classroom action research training, on the professional competence of elementary school teachers in the Undaan District, Kudus Regency.

The population in the study were all civil servants teachers in UPT District Education Undaan Kudus Regency. Population data is 191 people. In this study the sampling method is purposive (sampling with certain criteria), namely elementary school teachers who are civil servants, with a minimum of an S1 degree because the teacher qualifications must now be at least $\mathrm{S} 1$ and aged between 24 to 55 years on the grounds teachers who have these criteria are generally more productive. In addition, other criteria were that teachers who follow classroom action research training once and where training was not a determining factor in the sample. The research sample data of 111 people.

The intrument in this study was a questionnaire, a questionnaire prepared in the form of a statement regarding teacher professional competence, academic supervision and classroom 
action research training. Each instrument is developed from each variable to sub-variables, then indicators are determined to arrange the questions.

Before the instrument is used first, validity test is done by means of expert jugement, which is testing the instrument that has been made by researchers to expert lecturers, then the instrument is tested with 30 respondents of elementary school civil servants in Kudus according to sample criteria. Not involved when collecting data.

The analysis technique used in this study is descriptive statistics and regression analysis. The steps in analyzing data are selecting and classifying data, then analyzing the description of respondents characteristics and variable using SPSS, conducting prerequisite test analysis, conducting research hypothesis testing, and conducting data analysis to answer the problem formulation.

\section{Results and Discussion}

The implementation of academic supervision in the elementary school teachers in the Undaan District, Kudus Regency based on data obtained by researchers from 111 respondents showed that the implementation of academic supervision was obtained based on descriptive statistical calculations, which was a mean 55.37; median 57.00; standart deviation 8.513; range 39; minimum 28; maximum 67 . classroom action research training was obtained based on descriptive statistical calculations, which was a mean 60.21; median 59.00; standart deviation 9.388; range 30; minimum 43; maximum 73 . The professional competencies of teachers is obtained based on descriptive statistical calculations, which was a mean 89.99; median 89.00; standart deviation 13.706; range 54; minimum 56; maximum 110.

Academic supervision that has run quite well has turned out to affect the professional competence of teachers. That is shown from the results of data analysis using simple regression where the t-test value of 6.546 is known with a significance value of $0.00<0.05$, then $\mathrm{Ho}$ is rejected and $\mathrm{Ha}$ is accepted, which means there is an influence of academic supervision on the the professional competence of elementary school teachers in Undaan District. The contribution of academic supervision to the professional competence of elementary school teachers in Undaan District, Kudus Regency was 28.2\%.

The effect of academic supervision on the professional competencies of elementary school teachers in Undaan District, Kudus Regency can be seen in table 1 below :

Table 1. The effect of academic supervision on the professional competencies of elementary school teachers in Undaan District, Kudus Regency

\begin{tabular}{ccc}
\hline $\mathrm{t}$ & $\begin{array}{c}\text { Value } \\
\text { sig }\end{array}$ & $\begin{array}{c}\text { Big } \\
\text { Contribution } \\
(\%)\end{array}$ \\
\hline 6.546 & 0.000 & 28.2 \\
\hline
\end{tabular}

Academic supervision has an influence on the professional competence of elementary school teachers in Undaan District, Kudus Regency by $28.2 \%$.

Based on the data above, it can be concluded that academic supervision has an influence on the professional competencies of elementary school teachers. Academic supervision has an influence on the professional competence of elementary school teachers in Undaan District, Kudus Regency by $28.2 \%$. 
The results of the research in the field showed that classroom action research training affected the professional competence of elementary school teachers in Undaan District, Kudus Regency. This is indicated by the results of data analysis using simple regression where the calculated $t$ value of 11.956 with a significance value of $0.00<0.05$, then Ho is rejected and $\mathrm{Ha}$ is accepted, which means there is an influence of classroom action research training on the professional competence of elementary school teachers. The contribution of classroom action research training to the professional competence of elementary school teachers in Undaan District, Kudus Regency was 56.7\%.

The effect of classroom action research training on the professional competencies of elementary school teachers in Undaan District, Kudus Regency can be seen in table 2 below :

Table 2. The effect of classroom action research training on the professional competencies of elementary school teachers in Undaan District, Kudus Regency

\begin{tabular}{ccc}
\hline $\mathrm{t}$ & $\begin{array}{c}\text { Value } \\
\text { sig }\end{array}$ & $\begin{array}{c}\text { Big } \\
\text { Contribution } \\
(\%)\end{array}$ \\
\hline 11.956 & 0.000 & 56.7
\end{tabular}

Based on the data above, it was concluded that classroom action research training had an influence on the professional competence of elementary school teachers. Classroom action research training has an influence on the professional competence of elementary school teachers in Undaan District, Kudus Regency was 56.7\%.

SPSS output result obtained significance value probability ( $\mathrm{sig})=0.00=0 \%<5 \%$, this means that $\mathrm{Ho}$ is rejected and $\mathrm{Ha}$ is accepted. This means that there is an influence of academic supervision variable (X1) and classroom action research training (X2) together on the teacher's professional competency variable (Y). The magnitude of contribution of the variable academic supervision and classroom action research training together to variable of professional competence of elementary school teachers in Undaan District, Kudus Regency was $59.9 \%$.

\section{Conclusion and Suggestion}

\subsection{Conclusion}

Results of research in the field and data analysis conducted by researchers found several conclusions that there was an influence of academic supervision on the professional competence of elementary school teachers in Undaan District, Kudus Regency by $28.2 \%$. There is an influence of classroom action research training on the professional competence of elementary school teachers in Undaan District, Kudus Regency, which is $56.7 \%$. And there is also the influence of the variable of academic supervision and classroom action research training together to the variable of professional competence of elementary school teachers in Undaan District, Kudus Regency by $59.9 \%$.

\subsection{Suggestion}

Academic supervision conducted by school principals to elementary school teachers in Undaan District, Kudus Regency according to findings, was able to improve teacher professional competence. Therefore, the principal should continue to improve academic supervision activities so that the professional competence of teachers in his school increases. 
Improvement of supervision can be done by the school principal by conducting academic supervision in an intense, orderly, planned, and on going manner, so that teachers can get regular assistance and guidance. Likewise with the results showing classroom action research training can improve teacher professional competence. Therefore teachers are expected to take classroom action research training seriously so that their professional competence can increase.

\section{References}

[1] Arikunto Suharsimi, Lia Yuliana.2013.Manajemen Pendidikan.Sleman:Graha Cendekia

[2] Bafadal, I. (2009). Peningkatan profesionalisme guru sekolah dasar: Dalam kerangka manajemen peningkatan mutu berbasis sekolah. Jakarta: Bumi Aksara.

[3] Bangun, Wilson.2012.Manajemen Sumber Daya Manusia.Jakarta: Erlangga

[4] Hardono, Haryono, \& Amin Yusuf.(2017).Kepemimpinan Kepala Sekolah, Supervisi Akademik, dan Motivasi Kerja dalam Meningkatkan Kinerja Guru. Educational $\begin{array}{lllll}\text { Management. } & \text { EM } & 6 & \text { (1) 26-33 Retrieved from }\end{array}$ https://journal.unnes.ac.id/sju/index.php/eduman/article/view/16460

[5] Kompri. (2015). Manajemen sekolah: Orientasi kemandirian kepala sekolah. Yogyakarta: Pustaka Pelajar.

[6] Menkumham, Peraturan Pemerintah Republik Indonesia Nomor 19 Tahun 2005 tentangStandar Nasional Pendidikan, Sekretariat Negara RI, Jakarta, 2005

[7] Mulyanti, Anita Surya.(2018). Pengaruh Pelatihan dan Lingkungan Kerja terhadap Kinerja Guru dengan Kepuasan Kerja sebagai Variabel Intervening Di SD Muhammadiyah Condong Catur. Skripsi. Yogyakarta: Univeritas Islam Indonesia

[8] Mulyasa.2007. standar kompetensi dan sertifikasi guru. Bandung:PT remaja Rosdakarya

[9] Mulyasa, H. E. (2013). Uji kompetensi dan penilaian kinerja guru. Bandung: Rosda Karya.

[10] Mulyasa.2015.manajemen dan Kepemimpinan Kepala Sekolah.Jakarta:Bumi Aksara

[11] Pratiwi, asih.(2013).Pengaruh pelaksanaan MGMP IPA terpadu dan supervisi akademik oleh kepala sekolah terhadap kompetensi profesional guru ipa smp/mts se-kota magelang.Skripsi.Yogyakarta: Univeritas Negeri Yogyakarta.

[12] Sagala Syaiful.2010.supervisi pembelajaran dalam profesi pendidikan. Bandung:Alfabeta

[13] Saifuddin Azwar. (2013). Reliabilitas dan validitas. Yogyakarta: Pustaka Belajar.

[14] Sugiyono. (2015). Metode penelitian pendidikan pendekatan kuantitatif, kualitatif, dan $R \& D$. Bandung: Alfabeta.

[15] Sugiyono. (2010). Statistika Untuk Penelitian. Bandung: Alfabeta.

[16] Tampubolon Saur.2014.Penelitian Tindakan Kelas untuk Pengembangan Profesi Pendidik dan Keilmuan.Jakarta:Erlangga

[17] Wardhani, Kuswaya Wihardit.2014.Penelitian Tindakan Kelas.Tangerang Selatan:Universitas Terbuka.

[18] Workneh, A \& Tassew, W. (2013). Teacher Training and Development in Ethiopia. Young lives journal. Retrieved from https://assets.publishing.service.gov.uk/media/57a08a2c40f0b64974000474/yl-wp103abebe-woldehanna.pdf 